Gut, 1980, 21, 49-51

\title{
Prednisolone absorption in acute colitis
}

\author{
P R ELLIOTT, ${ }^{1}$ J POWELL-TUCK,,$^{2}$ P E GILLESPIE, ${ }^{3} \mathrm{~J}$ M LAIDLOW, \\ J E LENNARD-JONES, J ENGLISH, J CHAKRABORTY, AND V MARKS \\ From St. Mark's Hospital, London, and the Department of Biochemistry, University of Surrey, Guildford
}

SUMmaRY Peak plasma levels were reduced after an oral dose of $40 \mathrm{mg}$ prednisolone in six patients with severe acute colitis as compared with six normal subjects, though total absorption appeared to be similar; the findings suggest that prednisolone absorption was delayed in acute colitis. A dilutional fall in plasma albumin was observed in normal subjects and in the patients after $40 \mathrm{mg}$ prednisolone by mouth.

In severe acute colitis prednisolone is often given by intravenous infusion rather than by mouth, though there is no direct evidence that intestinal absorption of the drug is impaired. Previous observations have shown that the expected suppression of blood cortisol levels by oral prednisone may not occur in acute colitis, a fact that could indicate poor absorption (Friedman et al., 1969). Plasma prednisolone levels, measured by radioimmunoassay, after a single oral therapeutic dose of prednisolone in patients with severe acute colitis are compared in this study with the levels observed after the same dose in normal subjects.

\section{Methods}

\section{CLINICAL METHODS}

Six patients with severe acute colitis (Table 1) and six healthy volunteers were studied after obtaining their informed consent. Subjects fasted for 10 hours before, and during the eight hours after, taking $40 \mathrm{mg}$ prednisolone by mouth. Blood samples were withdrawn through an indwelling venous needle, kept patent with sodium citrate, before and 30 , $60,90,120,150,180,240,360$, and 480 minutes after the dose. Each sample was centrifuged immediately and the plasma stored at $-20^{\circ} \mathrm{C}$ until analysis.

'Address for reprint requests: P R Elliott, St. Mark's Hospital, City Road, London ECV1 2PS.

2Powell-Tuck, Wellcome Research Fellow, Clinical Nutrition and Metabolism Unit, Hospital for Tropical Disease, St. Pancras Way, London.

${ }^{3}$ Present address: P E Gillespie, Department of Gastroenterology, Westmead Hospital, Westmead, Sydney, Australia.

Received for publication 8 August 1979.

\section{LABORATORY METHODS}

Prednisolone assay

Prednisolone was measured by radioimmunoassay of an ethyl acetate extract of the plasma samples using an antiserum with a low cortisol cross-reactivity raised in sheep against prednisolone-21-hemisuccinate (Chakraborty et al., 1976, Henderson et al., 1979). As the dose levels-and therefore the blood levels-were relatively high, it was felt that the thin layer chromatography step, which eliminates cortisol interference, could be omitted. The cortisol crossreactivity with the antiserum used was $4 \%$. The residue from the ethyl acetate extract of plasma was dissolved in buffer and an aliquot used in the radioimmunoassay.

\section{Free prednisolone}

One millilitre of the plasma sample containing a trace amount of $6,7-{ }^{3} \mathrm{H}$-prednisolone $(100000 \mathrm{dpm}$; Sp. act $43 \mathrm{Ci} / \mathrm{mmol}$ ) was dialysed against $1 \mathrm{ml}$ phosphate buffer (pH 7.4, 0.1M) for 16 hours at room temperature. The solutions were contained in Teflon dialysis cells and separated by a Visking membrane. The percentage of the radiolabelled steroid which dialysed into the buffer was taken to be a reflection of the percentage of the non-protein bound prednisolone in the plasma.

Plasma albumin concentration was measured by the bromocresol green method (Hernandez et al., 1967). Prednisolone did not interfere with the assay either by altering the extinction coefficient or by shifting the wavelength of the peak colour formation.

\section{Statistical methods}

The statistical significance of the results was estimated using Student's $t$ test.

As the drug was administered orally it is not 
Table 1 Details of patients studied

\begin{tabular}{|c|c|c|c|c|c|c|c|c|}
\hline $\begin{array}{l}\text { Sex, } \\
\text { age } \\
(y r)\end{array}$ & $\begin{array}{l}\text { Temperature* } \\
\left({ }^{\circ} \mathrm{C}\right)\end{array}$ & $\begin{array}{l}\text { No.bowel action* } \\
(24 h)\end{array}$ & $\begin{array}{l}\text { Haemoglobin } \dagger \\
(\mathrm{g} / \mathrm{dl})\end{array}$ & $\begin{array}{l}E S R^{*} \\
(\mathrm{~mm} / \mathrm{h})\end{array}$ & $\begin{array}{l}\text { Baseline albumin } \dagger \\
(\mathrm{g} / \mathrm{l})\end{array}$ & $\begin{array}{l}\text { Extent of } \\
\text { disease }\end{array}$ & $\begin{array}{l}\text { Sigmoidoscopic } \\
\text { appearances }\end{array}$ & $\begin{array}{l}\text { Surgery same } \\
\text { admission }\end{array}$ \\
\hline M 52 & 38 & 5 & $8 \cdot 1$ & 88 & 33 & Extensive & $\begin{array}{l}\text { Spontaneous } \\
\text { haemorrhage }\end{array}$ & Yes \\
\hline F58 & $37 \cdot 8$ & 7 & $12 \cdot 6$ & 77 & 32 & Substantial & Friable & No \\
\hline F 31 & $37 \cdot 8$ & 6 & $11 \cdot 4$ & 40 & 36 & Extensive & $\begin{array}{l}\text { Spontaneous } \\
\text { haemorrhage }\end{array}$ & Yes \\
\hline F 23 & 37 & 9 & $10 \cdot 1$ & 100 & 28 & Extensive & $\begin{array}{l}\text { Minimal } \\
\text { abnormality } \ddagger\end{array}$ & No \\
\hline
\end{tabular}

*Highest in first 48 hours. †Lowest in first 48 hours. $¥$ Rectal sparing, probable Crohn’s disease.

possible to use the term 'plasma half-life' in its strict sense. The time taken for the plasma concentration of the drug to fall to half its maximal concentration was calculated from the log. concentration of the drug in the plasma against linear time.

The area under the plasma curve from zero to eight hours was calculated by numerical integration using the trapezoidal rule.
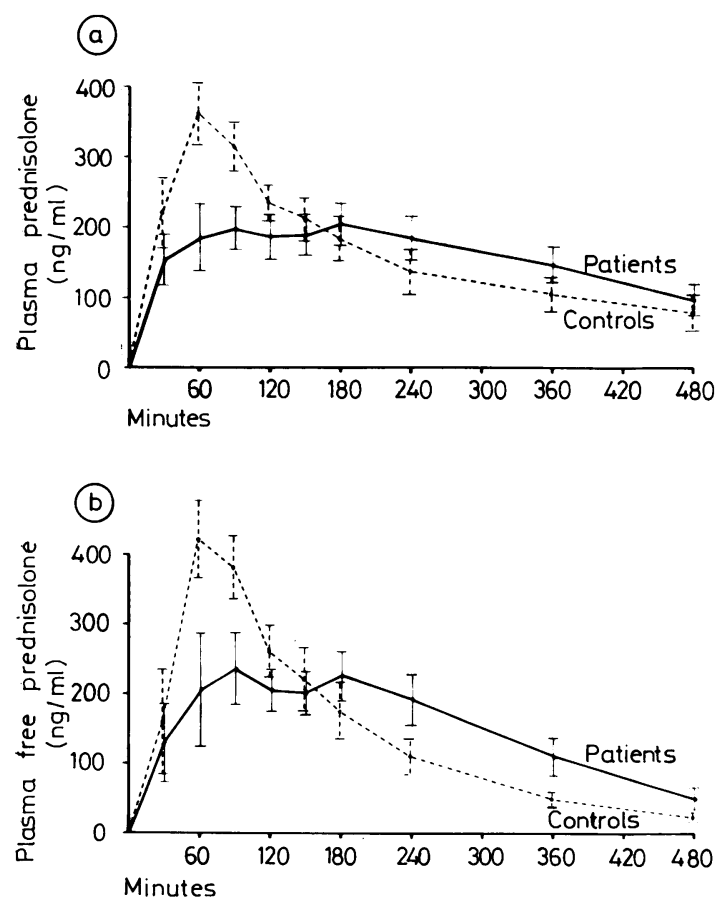

Fig. 1 (a) Plasma prednisolone measured in six patients with acute colitis and in six healthy volunteers after taking prednisolone $40 \mathrm{mg}$ orally (mean $\pm S E M$ ).

(b) Plasma free prednisolone measured in six patients with acute colitis and in six healthy volunteers after taking prednisolone $40 \mathrm{mg}$ orally (mean $\pm S E M$ ).

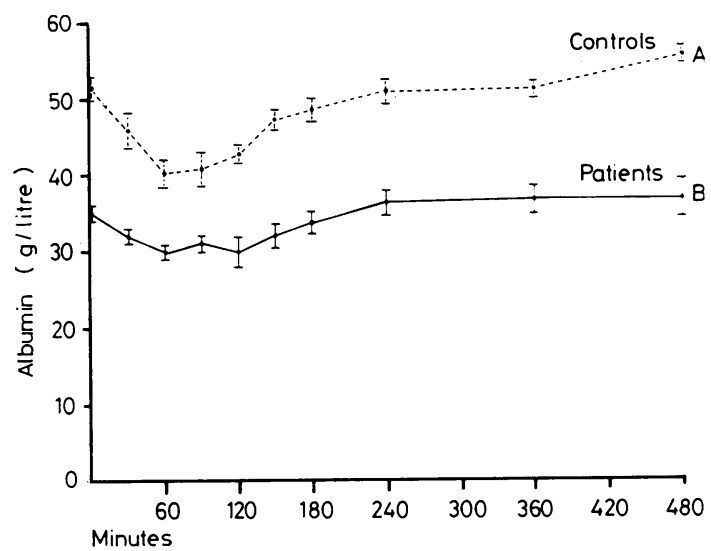

Fig. 2 Plasma albumin measured in six patients with acute colitis and in six healthy volunteers after taking prednisolone $40 \mathrm{mg}$ orally (mean $\pm S E M$ ).

\section{Results}

PLASMA PREDNISOLONE LEVELS (Fig. 1a and b) The mean total plasma prednisolone at 60 minutes was less $(\mathrm{P}<0.01)$ in the patients $(181 \mathrm{ng} / \mathrm{ml} \pm 47$ SEM) than in the control subjects $(362 \pm 41)$. At 180 minutes, and thereafter, the mean plasma levels of the patients tended to be higher than the controls. Results for mean plasma free prednisolone paralleled these results.

The area under the curves for total and free prednisolone over the eight hour study period was similar for patients and controls (Table 2). The time taken for the plasma concentration of the drug to fall to half its maximal concentration was markedly longer in the patients $(\mathrm{P}<\cdot 001)$.

PlaSMA ALBUMin LEVELS (Fig. 2)

Plasma albumin levels were less $(\mathrm{P}<0.001)$ in the patients than in the controls. The levels dropped 
Table 2 Mean values $( \pm S E M)$ for total and free prednisolone

\begin{tabular}{|c|c|c|c|c|c|c|c|}
\hline \multirow[t]{2}{*}{ Subjects } & \multicolumn{4}{|c|}{ Total prednisolone } & \multicolumn{3}{|c|}{ Free prednisolone } \\
\hline & $\begin{array}{l}\text { Peak } \\
\text { time } \\
\text { (min) }\end{array}$ & $\begin{array}{l}\text { Peak } \\
\text { concentration } \\
(\text { ng/ml })\end{array}$ & $\begin{array}{l}\text { Area } \\
\text { under curve } \\
(\mathrm{ng} / \mathrm{ml} / \mathrm{h})\end{array}$ & $\begin{array}{l}T 1 / 2 \\
(\min )\end{array}$ & $\begin{array}{c}\text { Peak } \\
\text { time } \\
(\text { min })\end{array}$ & $\begin{array}{l}\text { Peak } \\
\text { concentration } \\
(\text { ng/ml })\end{array}$ & $\begin{array}{l}\text { Area } \\
\text { under curve } \\
\text { (ng/ml/h) }\end{array}$ \\
\hline $\begin{array}{l}\text { Patients } \\
\text { ( } \pm \text { SEM) } \\
\text { Controls } \\
\pm \text { SEM })\end{array}$ & $\begin{array}{l}180 \\
60\end{array}$ & $\begin{array}{c}206^{*} \\
\pm 35 \\
362^{*} \\
\pm 44\end{array}$ & $\begin{array}{l}1236 \\
\pm 167 \\
1305 \\
\pm 155\end{array}$ & $\begin{array}{c}300 \dagger \\
\pm 24 \\
138 \dagger \\
\pm 36\end{array}$ & $\begin{array}{l}90 \\
60\end{array}$ & $\begin{array}{l}47 \\
\pm 10 \\
84 \\
\pm 11\end{array}$ & $\begin{array}{l}251 \\
\pm 36 \\
232 \\
\pm 25\end{array}$ \\
\hline
\end{tabular}

$*<0.01 . \dagger-<0.001$.

$(P<0.02)$ in the control subjects to a minimum 60 minutes after the dose of prednisolone and a similar trend was seen in the patients from 0-240 minutes after the dose. The reduction in plasma albumin was paralleled by reductions in the plasma concentrations of urea, sodium, and free fatty acids.

\section{Discussion}

This study does not show that the total absorption of prednisolone differs between patients with severe acute colitis and normal subjects, but it has suggested a different pattern of absorption. A higher peak level of total prednisolone occurred in normal subjects, and free prednisolone followed the same trend. Later results showed a tendency for the levels in the patients to fall more slowly than in the control subjects. The most likely explanation of this finding is delayed absorption of prednisolone from the gastrointestinal tract of patients with severe acute colitis. Reduced plasma clearance as a major cause of the sustained plasma levels in patients seems unlikely, as peak levels were earlier and higher in normal subjects.

The possible clinical significance of delayed absorption with a low peak and prolonged rise of plasma prednisolone levels in the patients is uncertain. A clinical trial has shown that prednisolone $40 \mathrm{mg}$ given in one oral dose daily appears to be therapeutically equivalent to four doses of $10 \mathrm{mg}$ taken at intervals through the day (Powell-Tuck et al., 1978), a finding which suggests that total absorption is more important than the peak level achieved. As the area under the curve in both normal subjects and patients with acute colitis in this experimental study was similar, it is likely that the total prednisolone absorbed was the same and the results of the controlled trial suggest that delayed absorption should not alter the efficacy of this orally administered prednisolone.

A surprise finding after prednisolone administration in control subjects was the fall of plasma albumin by about $20 \%$ of the original value at 60 minutes and which persisted to a lesser degree for three to four hours after the dose. A similar fall by about $14 \%$ occurred in the patients. This change was most likely to be dilutional because the concentration of urea, sodium, and free fatty acids also fell. The observation is analogous to that of Lahdensuu et al., (1975) who found a fall in haematocrit of traumatised rabbits after methyl prednisolone.

We are grateful to Miss Brenda Roach for secretarial assistance and Mr. Lloyd Soodeen for technical assistance. J.P-T. was supported by the St. Mark's Research Foundation, P.R.E. was supported by the Sir Halley Stewart Trust, P.E.G. was supported by the New South Wales Cancer Council, Australia and J.E. was supported by Pharmax Ltd., Bexley, Kent.

\section{References}

Chakraborty, J., English, J., Marks, V., Dumasia, M. C., and Chapman D. J. (1976). A radioimmunoassay method for prednisolone: comparison with the competitive protein binding method. British Journal of Clinical Pharmacology, 3, 903-906.

Friedman, M., Hinton, J. M., and Lennard-Jones, J. E. (1969). Adrenal and clinical responses to corticotrophin and prednisone in inflammatory disease of the colon. Gut, 10, 194-197.

Hernandez, O., Murray, L., and Doumas, B. (1967). Automated determination of serum albumin with bromocresol green (Abstract). Clinical Chemistry, 13,701 .

Henderson, R. G., Wheatley, T., English, J., Chakraborty, J., and Marks V. (1979). Variations in plasma prednisolone concentrations in renal transplant recipients given enteric-coated prednisolone. British Medical Journal, 1, 1534-1536.

Lahdensuu, M., Alho, A., and Rokkanen, P. (1975). The effect of drug therapy without volume restoration in experimental traumatic shock. Part 3. Glucocorticoid. Annales Chirurgiae et Gynaecologiae Fenniae, 64, 7073.

Powell-Tuck, J., Bown, R. L., and Lennard-Jones, J. E. (1978). A comparison of oral prednisolone given as single or multiple daily doses for active proctocolitis. Scandinavian '. urnal of Gastroenterology, 13, 833-837. 